THIS IS AN AUTHOR'S POST-PRINT ORIGINAL MANUSCRIPT OF AN ARTICLE SUBMITTED FOR CONSIDERATION IN THE PLANNING PERSPECTIVES JOURNAL [COPYRIGHT TAYLOR \& FRANCIS]; THE FINAL AND PUBLISHED VERSION IS AVAILABLE ONLINE AT:

HTTP://WWW.TANDFONLINE.COM/DOI/ABS/10.1080/02665433.2013.824369\#.U

KCWBBYXNZU

\title{
Green Wedges: Origins and Development in Britain
}

\section{Introduction}

The origins of park system planning in the second half of the nineteenth century and its subsequent development have been widely debated within the literature. Dal $\mathrm{Co}^{1}$ pointed out that since their inception park systems were essential instruments of planning and Dümpelmann ${ }^{2}$ elaborated on how they soon became central to planning debates across the Western world. Out of the myriad of types of green spaces emerging then, the greenbelt has received abundant attention. But while its importance has been thoroughly examined, ${ }^{3}$ a review of the literature shows that relatively little is known about the 'green wedge' - even though planners widely discussed the idea in the first half of the twentieth century. Aiming at contributing to fill this gap, this paper focuses on the history of the green wedge in Britain. Central to our argument is the fact that the green wedge played a fundamental role as a new element of park system proposals, since it emerged from the idea of radial parks, in the late 1900s, to gain widespread recognition as a valid alternative or complement to the greenbelt in interwar Britain.

Green wedges were proposed as ducts of green space from the countryside right into the centre of a city or town. The wedge form would funnel air, sunlight and greenery inside the urban fabric regardless of urban sprawl, as the wedge could likewise expand. If the greenbelt was physically a peripheral element around a town thought, among other things, to control urban growth and to separate urban and rural areas, the green wedge aimed to provide salubrious intra-urban green space and a through connection to the countryside.

The paper sets out to contextualise the precedents of the green wedge idea in relation to the history of park systems and their integration with traffic systems. Secondly, it focuses on how the concept became recognised as a distinct typology of radial green space in Britain in the first decade of the twentieth century. It emphasises the role of the 1910 RIBA Town Planning Conference in the dissemination of the concept and its immediate reception. Subsequently, the paper considers how green wedges permeated British planning debates up to the Second World War, including how individual actors - such as T. H. Mawson, H. V. Lanchester, P. Abercrombie and R. Unwin - attempted to implement them. The paper considers both texts and plans, and focuses on early twentieth-century proposals for London.

\section{Origins of the green wedges idea}

According to Giedion, ${ }^{4}$ the task of bringing air, sunlight and greenery to the urban environment was a priority for the first modern planners. Overcrowding, poor housing, urban sprawl, pollution, unsanitary conditions, lack of green spaces and congestion were common aspects of industrial cities, particularly across England and Germany. ${ }^{5}$ 
In Britain, numerous reports on pollution and the lack of green spaces were produced in the nineteenth century. Sir Richard Phillips, for instance, wrote in 1817 that the smoke in London was indeed found to 'destroy all vegetation'. ${ }^{6}$ The miasmatic situation of many industrial towns was seen as a severe threat to the physical, mental and moral conditions of urban dwellers, which led to the emergence of the public health movement and the parks movement. ${ }^{7}$ One of the first noteworthy proposals to decisively try to control London's growth and re-establish its balance with nature came from the landscape architect John Claudius Loudon in his 1829 plan. ${ }^{8}$ Loudon aimed to combine town and country by providing a framework for the growth of London that would keep this balance unaltered irrespective of how much the city expanded. The plan comprised concentric rings of built-up areas separated by greenbelts and cut through by a green wedge. Despite being a predominant feature, the latter - the first green wedge ever seen in large plans for the capital - is often ignored by the literature. ' Loudon's open spaces were to be zones of 'country' and 'breathing places', allowing every inhabitant to access open air without the need to walk more than half a mile.

In the United States, F. L. Olmsted's publication of Public Parks and the Enlargement of Towns and his plan with C. Vaux for Buffalo, from 1868-9, constituted, respectively, a theoretical framework and a practical application of the park system idea. ${ }^{10}$ Park systems spread rapidly not only in the United States, but also in Europe. The transformation of the Ringstrasse in Vienna, as well as the park system implemented during Haussmann's period as Préfet de la Seine by Adolphe Alphand, became references across the world. In Germany, Joseph Stübben in his 1890 book, Handbuch der Architektur, defended the creation of park systems in advance of development and their integration with radio-concentric traffic systems. Park systems should include, among other typologies, park-promenaden, which would not only link the different types of green space within the urban fabric, but also radially connect the city to the countryside - one of the main features of the green wedge, which would be formally theorised some years later. ${ }^{11}$ In France, Stübben's recommendation for the integration of radial arteries and ring roads with green spaces was adopted in the 1900s plan for Paris by Eugènne Hénard, who was also a great admirer of London's squares and parks, particularly of the fact that they were not concentrated in a few locations, but spread across the city. ${ }^{12}$ The British initial contribution to the development of park systems came with Howards' promotion of the greenbelt.

In the period between the last quarter of the nineteenth century and the First World War, urban sprawl and an anti-urban popular perception intensified. Hall showed that the implementation of public transport systems in British cities at the time, especially electric trams and motor buses, had a profound impact on urban growth and suburbanisation. London began to spread in all directions, the result being a tentacular form of growth stretched along traffic lines and pockets of development around stations. ${ }^{13}$ Uncontrolled sprawl and the impact of the environment on urban dwellers were prominent issues to be dealt with.

The exchange of planning ideas between Europe and the Americas, and within European countries, was intense in the period. ${ }^{14}$ Werner Hegemann's presence in New York and Philadelphia in 1909 and Daniel Burnham, Charles McKim and Olmsted's European tour, organised by the Senate Park Commission in preparation for the Plan of Chicago, are clear examples of that. In addition, in that very same year - the year of the passing of the first Housing and Town Planning Act in Britain, which made statutory town planning a function of local governments - around 80 British town 
councillors attended a field trip to Germany to study expansion plans. This was reciprocated by a group of 200 members of the German Garden City Association visiting England in July that year. ${ }^{15}$ In fact, the minutes of the RIBA Town Planning Committee meetings give a clear insight into how the United States and Germany were the main sources of inspiration in matters of town extension and park system planning in Britain. For instance, in 1907, the 'Development of Towns and Suburbs Committee' decided to send out letters to prominent planning figures such as Peabody in Boston, Miles Day in Philadelphia, McKim in New York, Carey in Buffalo and Stübben in Cologne to obtain information on this subject in their countries. ${ }^{16}$

Still in the 1900s, the questions of whether a town should grow indefinitely or not, and how best to connect it to expansion areas, were central to planning debates. The ring model generally involved circular development areas and a peripheral ring road, from which radial arteries would be laid out towards the expansion areas. Yet, concentric development soon proved to be questionable and deemed, by authors such as Stübben and Hénard, inappropriate for coping with the 'octopus-like' nature of many towns. The benefits of associating park and traffic systems became evident, and while the most important element of concentric traffic system plans, the ring road, had its green counterpart - the greenbelt - the radial system had not yet found its prime green equivalent. Although, the term 'radial park' was generically used to describe green spaces radiating out from inner urban areas, the 'green wedge' soon became its strongest manifestation.

An early theoretical argument in Britain in favour of radial parks can be seen in Henry Vaughan Lanchester's article from 1908 entitled Park Systems for Great Cities. He was a very active member of the RIBA, would later become secretary of the 1910 RIBA Town Planning Conference and one of the founders of the Town Planning Institute. In this article, he analysed a number of significant park systems of the period, such as the plans for Boston, Chicago, Rhode Island and Washington. He was supportive of the American use of parkways and radial parks, and challenged the efficacy of greenbelts. Lanchester presented a diagram illustrating how green spaces radiating outwards should be located amidst built-up areas:

The suggestions that have hitherto been made in this country as regards the comprehensive arrangement of open spaces seem to indicate a prevalent view that parks and recreationgrounds should form a ring round the city; it is, however, difficult to see on what basis this view rests $(. .$.$) - the parks themselves should certainly be placed radially. { }^{17}$

He stressed that the greenbelt owed its inception to cases where a chain of open spaces took the place of obsolete fortifications, as in the Ringstrasse in Vienna, and although it had proliferated in Britain, it should be abandoned. Lanchester, who was familiar with Hénard's studies on traffic systems mentioned above, ${ }^{18}$ developed his argument, stating that:

it is clear that a series of parks placed radially is the more reasonable method. For one thing, they do not define the city area and exercise a restrictive influence on the space within them; for another, they lead from the more densely populated areas out into the open country, thus encouraging a general exodus towards it, and they also adapt themselves to the gradual expansion of the city. ${ }^{19}$

Figure 1. Lanchester's 1908 diagram and park system plan for the 'Northern Environs' of London. Source: Lanchester, "Park Systems for Great Cities", 343 and 345. 
Lanchester applied this idea to London and suggested that, although the capital was well off in the matter of open spaces, these were scattered about - just as Hénard had previously stated - and provided no connection to the countryside. He presented two plans for a park system: one for the 'Northern Environs' and one for the 'Southern Environs'. The existing and proposed open spaces were linked up by boulevards and parkways ${ }^{20}$ and a significant park in a wedge form was demarcated in Epping Forest (Figure 1). In 1909, Lanchester pursued the idea in a lecture at the RIBA, reported by The Times on February 19. At the presentation, which was attended by Raymond Unwin, Lanchester argued that 'the country was in course of being wrecked and broken up' and that for the improvements of towns 'the first thing to be demanded was the provision of worthy routes connecting the centre with the open country'. Although Lanchester had not specifically used the term 'green wedge', he set forth the parameters for its theoretical construction in the following years. Its first main functions were defined: to connect the town and the country, and to bring greenery and fresh air to the inner parts of the urban fabric.

\section{The 1910 RIBA Town Planning Conference: radial planning and the emergence of green wedges}

In this period of intense planning research and extensive exchange of ideas, there is no account of the role that the first ever town planning conference and its transactions played in the debates regarding the articulation of traffic and park systems in general master-plans. This section highlights the importance of the Conference, and of its transactions, in this regard and in propagating one of the most innovative contributions to the debates on park system planning: the idea of green wedges.

The Conference took place a year after the passing of the 1909 Town Planning Act. Dozens of newspapers and journals published various notes and articles about the event. Statements such as: 'it will be the most important of its kind that has yet been organised in this country' (Manchester, August 10, 1910) were not uncommon. Indeed, the conference received around 1,500 delegates from various parts of the world. Among the participants were: Joseph Stübben, Werner Hegemann and Rudolf Eberstadt from Germany; Raymond Unwin, Henry V. Lanchester, Stanley Adshead, Barry Parker, Thomas Mawson, Thomas Adams and Ebenezer Howard from the United Kingdom; Daniel Burnham and Charles Robinson from the United States; and Eugène Hénard, Louis Bonnier and Augustin Rey from France. The event comprised paper presentation sessions as well as exhibitions, site visits and other social activities. Germany, the leading nation in the field, ${ }^{21}$ was by far the largest contributor to the exhibition - which was organised by Unwin - presenting plans for the Greater Berlin Competition, Munich, Cologne, Dusseldorf, Nuremberg and other cities. It was followed by the United States, with Burnham's Chicago plan; Great Britain, mostly featuring Letchworth, plans for garden suburbs, such as Hampstead, Bourneville and Port Sunlight, as well as Geddes' survey of Edinburgh; France, showcasing plans for Paris; and minor contributors, such as Italy, Sweden and other Scandinavian countries.

The 1910 RIBA Town Planning Conference is often mentioned by the literature in relation to its wide historical context and significance in defending architectural considerations in town planning. ${ }^{22}$ In fact, there is no evidence that questions of traffic systems models and green spaces were at the forefront of the minds of the organising committee from the outset, ${ }^{23}$ yet, as this paper argues, they became central subjects of discussion. The Conference saw an intense debate over which model was more advantageous: the concentric or the radial. Notable proposals in favour of the first 
strategy came from A. Crow ${ }^{24}$ and G. L. Pepler. ${ }^{25}$ Supporting the focus on the latter, contributions by F. S. Baker, C. M. Robinson, R. Eberstadt and Lanchester were particularly relevant. Pepler, one of the future founders of the London Society and the Town Planning Institute, suggested the creation of a 'great girdle' surrounding Greater London, to facilitate traffic and to provide a framework for the creation of a belt of garden suburbs around the capital. Crow's most interesting discussion on the construction of 'Ten Cities of Health' around London also pointed towards the creation of a ring, but of garden cities. Nonetheless, there was a clear tendency at the Conference towards the radial approach. For instance, Baker, representing the Royal Architectural Institute of Canada, stated: 'what an important thing it was for a town to have radiating streets running out to the suburbs' ${ }^{26}$ Robinson also focused in his paper on the connections between the centre and the suburbs. He pointed towards the provision of long, straight and wide radial roads, which would shorten the travelling time and distance to the outer zones, and by doing so allow citizens to live outside the inner city. This possibility, according to Robinson, was 'the triumph of the modern city' ${ }^{27}$

One of the most fervent crusaders for radial development and its integration with the planning of green spaces was the German engineer Rudolf Eberstadt. At the Conference, he presented his runner-up entry - co-authored by Richard Petersen and Bruno Möhring - to the 1910 Greater Berlin Competition. Eberstadt lambasted the repetition of concentric patterns of growth (Figure 2), arguing that 'every ring, whatever its name may be, is injurious and hurtful to town extension. (...) For the modern town, however, we must break down the ring; the pattern for modern town extension is the radial pattern. The backbone of town extension is formed by the traffic line'. Not linking green areas to the radial patterns in vogue was, for Eberstadt, a missed opportunity and a lack of integrative thinking: 'the open spaces are not green islands accidentally dispersed round the town, but systematically arranged, so as to procure open spaces and circulation of fresh air in all parts of the town'. ${ }^{28}$

Figure 2. Eberstadt's opposing diagrams of concentric rings and green wedges.

Source: Eberstadt, "Town Planning in Germany", 328.

He expanded his argument presenting the idea of green wedges, which would be the new typology appropriate for the modern city. These should be created along the radial arteries as channels of greenery, sunlight and fresh air. Their wedge form wider in the countryside and narrower in the city centre - was thought to maximise and direct these flows, as well as to follow the logic that land on the outskirts was cheaper and therefore more accessible for local authorities to convert into parks.

Eberstadt was not the only one to speak about the idea. Lanchester read a paper along similar lines, in which he revealed a diagram, only slightly different from the 1908 one, depicting how green wedges should be used (Figure 3). It showed a generic city model with green wedges extending from the countryside into the city centre, cutting through residential districts. ${ }^{29}$ This proposal was also further discussed in an informal evening meeting 'by the lantern', when he showed how this principle could be applied to North London and areas south of the Thames, following his initial studies of $1908 .{ }^{30}$

Figure 3. Lanchester's diagram of a model city with green wedges. Source: Lanchester, "Cause and Effect in the Modern City, 234. 
Werner Hegemann, who had been Secretary-General to the Berlin Exhibition, commenting on Lanchester's presentation, pointed out the benefits of such an approach and held up Eberstadt's plan for the German capital as an example of how the green wedge idea could be applied by 'not only bringing the traffic in a radial way to the centre, but also the parks, providing thus a broadcast fresh-air drainage to the whole city, and giving a chance to the people to get from every point of the city some park that in a radiating way reaches the broader green areas beyond' ${ }^{31}$ John Brodie, City Engineer of Liverpool and a fellow participant at the Conference, also favoured the solution, arguing that 'Mr Lanchester has hit upon, I think, the right idea'. He explained that it would be a tendency to combine wide streets with open spaces as part of the park system of a town. In addition, Brodie was critical of 'the oldfashioned park areas dotted about irregularly', and that it was 'very much better to carry your park-like areas out with you radially'. ${ }^{32}$ In a similar vein, in the presentation entitled Bruxelles Aux Champs, Stasse and de Bruyne made a strong case for the creation of 'a series of parks and avenues pleasantly leading the pedestrian (...) from the reverberating furnace of the centre to the open air, the green depths of Nature and infinite space'. To reinforce their disgust with a 'few patches of verdure' and to make their allegiance to the idea of green wedges more explicit, they maintained that:

What we want is to break up this frontal border by means of big, wedge-like plantations, penetrating far in; to transform the circular expansion of the town into a star-like-shaped figure, between the points of which would be preserved for ever bright and breezy intervals promising better things beyond. ${ }^{33}$

Mawson, the acclaimed landscape architect and lecturer at Liverpool University, made yet another notable contribution to the debates about how and where to create parks in a city. Like Eberstadt and Lanchester, he too highlighted the supposed opposite nature of the green wedge concept in relation to the greenbelt:

There are two principles on which park schemes may be developed; these are shown in diagrams prepared, I believe, by Professor Eberstadt. The first is known as the belt, the other as the radial plan. (...) All town-planners, (...) who have seriously studied the development of park schemes agreed that the radial principle is the best, as it ensures an unbroken current of fresh air into the city, takes the least land where it is most expensive, and the most on the agricultural fringe; but most important of all, it ensures an expanding proportion of park as the population increases. ${ }^{34}$

A somewhat unusual supporter of the green wedges at the Conference can be found in Colonel G. T. Plunkett. ${ }^{35}$ Rather than urban parks, the green wedges were considered to be stretches of natural scenery, bands of countryside within the city and reserves for wild creatures. Instead of suggesting that they follow the radial arteries of the traffic system, Plunkett advocated that these green spaces be created along rivers and brooks, in a similar fashion to the American greenways.

As discussed, the RIBA Town Planning Conference and its Transactions played a fundamental role in promoting radial traffic systems and their connection to park system planning. As a consequence, the green wedge emerged as the most appropriate typology to be linked to radial arteries and geographical features, such as river valleys and areas of natural beauty left over by urban development. It was initially presented as a concept opposed to the greenbelt and its main functions were to bring fresh air and greenery into the city, and to provide a direct way to the countryside. The benefits 
of its shape were theorised and clarified. In practical terms, it would promote a funnelling effect for the wind and increase the area of green space as the city grew. In a more abstract way, it symbolised a connection to the beauty of nature and its beneficial psychological effects on the population. The diffusion of the idea of green wedges itself was the most important contribution of the RIBA Town Planning Conference to park system planning and design in Britain.

\section{Green Wedges in Britain after the 1910 RIBA Conference}

The Conference was reported in many British journals and newspapers. The majority of publications commented on the kaleidoscopic nature of the event, the large number of countries represented and how town planning had become a subject to be discussed not only by experts, but also by the public at large. ${ }^{36}$ The Conference transactions were awaited with great anticipation. Adshead, professor of Civic Design at Liverpool University and one of the Conference organisers, stated that: 'there is no doubt it will be the most valuable piece of literature on town planning yet published, and should be acquired without delay'. Aside from that - and perhaps more importantly - Adshead acknowledged that despite the early efforts of the organisers to focus on the importance of architectural considerations, 'several of the papers, it is true, deal with different aspects of the subject'; and that 'on glancing through them again we are led to feel the great permanent value of collecting together those chiefly responsible for Town Planning throughout the world, and letting them say what is uppermost in their minds'. ${ }^{37}$ Once published, many commentators emphasised the Transactions' fundamental significance to the development of town planning as a disciplinary field. ${ }^{38}$ It is true that the Conference gathered the most recognised experts in the field and established a forum for the propagation of ideas; however, it was through the circulation of key participants, their papers and plans that those debates became widely disseminated.

The idea of green wedges started to permeate debates in Britain in the months immediately after the RIBA event. In October 1910, the Town Planning Review published a copy of Mawson's paper presented at the Conference, followed by a critical review of the St Louis Park System proposal, condemning its lack of green wedges: 'the map, of course, is only tentative, but it appears to us rather to neglect the provision of radial wedge park-ways, providing a series of concentric rings only connected by ordinary traffic routes' ${ }^{39}$ Patrick Abercrombie became one of the most important names to advocate the idea post-RIBA Conference. In 1912, in the article 'Town Planning in Greater London: the need for co-operation', he argued in favour of a conjoined treatment of open spaces across Greater London and drew attention to the case of Finchley. ${ }^{40}$ Abercrombie pointed out that under the 1909 Town Planning Act, Finchley and 'Brent Garden Suburbs' were being 'developed on modern lines' and that a green wedge was to be formed in the district. Hampstead Garden Suburb, Hampstead Heath and Parliament Hill would form this axis, inserting 'a continuous wedge of green into London', and providing thus a through connection to the country. ${ }^{41}$ He pondered over how many other green wedges could be created in the city and how in fact they could become elements of any park system. With this idea in mind, he was invited to be the assessor of a town planning competition for York. In the introduction to his report he argues that the shape of the city's existing open spaces forms 'a natural series of radiating wedges from the centre', and that 'the nucleus of a magnificent park system is in existence already, and it must have been one of the most congenial tasks put before the competitors to make the most of this wonderful opportunity for creating the finest park system in the country'. ${ }^{42}$ Not 
surprisingly, the winning proposal, by Reginald Dann, was the one that had applied such an idea. Commenting on its qualities, Abercrombie stressed that the park system was 'particularly good', working 'strongly on the principle of radial parks rather than ring parks'. ${ }^{43}$

Notably, Eberstadt's and Lanchester's diagrams prompted reflections from a wide number of professionals of different disciplines. Mawson elaborated further on the theme. In a series of lectures given at Bolton in 1915, he started to call the models on which park systems were based the 'Ringstrasse' and the 'radial'. He used Eberstadt's arguments and diagrams to describe the green wedges as:

open areas stretching almost to the heart of the town from the country and so bringing in fresh air to where it is most needed, along ducts of greenery, but these wedges of greenery are naturally narrowest near the centre of the town and broadest in the suburbs, where land is cheaper and where larger parks are more called for, and more practicable. It will also readily be seen that these wedges of greenery fall very naturally into their places as a part of the park system, and the proper layout of a modern town. ${ }^{44}$

For Bolton, he suggested a combined approach of ring parks and green wedges. It started to become apparent that greenbelts and green wedges did not need to exclude each other - in fact they did not in many plans of the following years.

\section{The London Society Development Plan}

The flamboyancy and breadth of the Plan for Chicago, the regional scope of Geddes's Civic Survey of Edinburgh and of the Greater Berlin plan - all of which were exhibited at 1910 RIBA Town Planning Conference - brought into focus the lack of an overall plan for London and served as an impetus for British planners to work towards one. It became evident that planning had to be a regional activity. ${ }^{45}$ Hewitt highlighted how Pepler's ambition to promote regional planning at the Conference soon gained momentum with the creation of the London Society in $1912 .{ }^{46}$ As was to be expected, most of its first members had taken part in the RIBA event, including Pepler, Adshead, T. Adams, Unwin, Lanchester, J. Burns, L. Stokes, B. Pite and W. E. Riley, among others. The Society was concerned with the form of development of its object of study: 'London is an immense octopus and its tentacles spread further afield, north, south, east and west, with no one to guide them. It is the endeavour of our Society to insist on some plan which shall govern the movements of the octopus'. ${ }^{47}$ From 1914 to 1918 , the Society prepared what has been called the Development Plan of Greater London, focusing on arterial roads and the provision of green spaces ${ }^{48}$ Unwin was responsible for surveying the capital's open spaces, ${ }^{49}$ while Lanchester was one of the specialists directly involved with the traffic system. ${ }^{50} \mathrm{~A}$ series of radial arteries was envisaged to address increasing congestion and connectivity problems arising from ribbon development. The park system of the Development Plan focused on linking up existing and new open spaces, and included green wedges. The proposal contained a wedge-like regional park radiating outwards in north-west London, from Stanmore to the Brent Reservoir, and another one in the Epping Forest, coinciding with Lanchester's 1908 plan. (Figure 4)

Figure 4. London Society Development plan 1918.

Source: London Society Archives

It is worth pointing out that up to that point Unwin had not yet endorsed the application of the green wedges idea in Britain, despite his appreciation of the concept 
for Greater Berlin. He had visited the Berlin Städtebau Ausstellung just months before the RIBA event and highly praised Eberstadt's solution to create green wedges as a means of increasing the presence of greenery in large cities. ${ }^{51}$ At the RIBA Conference, he was eclectic with regard to the ideal traffic system, stating that in a good modern plan, in addition to the radiating lines, certain cross diagonals will be required, and roads roughly following circular lines round the town will also probably be found necessary' ${ }^{52}$ With regard to open spaces, he had promoted the idea of surrounding buildings and urban settlements with greenery, which he would later develop in Nothing Gained by Overcrowding, in 1912. As for London, he had been thoroughly involved in discussions about the value of a greenbelt. ${ }^{53}$ Although the green wedges were still incipient in the London Society Development Plan, it announces their use in subsequent plans for the capital.

\section{The interwar period and the consolidation of the green wedges idea}

Although this paper focuses on the development of the green wedges idea in Britain, it is worth mentioning that the concept also found fertile ground in other lands. For instance, the American town planner Nelson Peter Lewis, in his book Planning of the Modern City, made reference to Brodie's and Hegemann's favourable opinions regarding green wedges published in the Transactions. ${ }^{54}$ As discussed earlier, interchanges of plans, books and professionals between Europe and the Americas were intense at that period. ${ }^{55}$ The development of the green wedge idea in Germany, particularly, needs a separate study. Since Eberstadt, Petersen and Möhring's plan for Greater Berlin, green wedges appeared in a large number of diagrams and plans, including Robert Schmidt's study for Ruhr from 1912, ${ }^{56}$ Bruno Taut's Die Städtkrone from $1919^{57}$ and Gustav Langen's 1927 study. ${ }^{58}$ In Latin America, the idea was adopted by Jean Claude Forestier in his 1923 plan for Cuba, by the French architect Alfred Agache in his 1930 plan for Rio de Janeiro ${ }^{59}$ and by the engineer Prestes Maia in his Avenue Plan for São Paulo of the same year. ${ }^{60}$ In Australia, John Sulman - who at the RIBA Town Planning Conference had presented a paper on the plan for the federal capital of Australia - made his own version of Eberstadt's diagrams and published them in 1919. The idea, as Freestone demonstrated, was influential in major plans for Melbourne in 1929 and Perth in $1930 .{ }^{61}$ Wedges would also play an important role in the Regional Plan of New York and its Environs, published in 1929. For Adams, the Central Park was 'the point of a wedge in a north-western system of parks' ${ }^{62} \mathrm{He}$ also argued that wedges should be used for the creation of agricultural zones ${ }^{63}$ which in Britain at the time was most exclusively a task for greenbelts or girdles. Green wedges continued to be used in the post-war context nationally, in plans for London and for the new towns, and internationally - the 1947 Copenhagen Finger Plan being the most famous materialisation of the concept.

In Britain, Cherry showed how the interwar period was marked by difficulties in controlling the onrush of speculative building, the threat of the loss of open countryside, congestion in inner urban areas and the need for road improvements. ${ }^{64}$ Facing the problems of the relationship between town and country led to the need to focus on regional plans. The lack of open spaces was also a pressing issue. The protection of natural beauty was a moral duty, while it was held that contact with nature would help to regenerate physical and mental health. Not surprisingly, a vision for the creation and preservation of open spaces was central to any development plan, at town and regional levels - and in these circumstances the green wedges received even more attention. 
It is worth noting that in 1923, Pepler published an article titled 'Open Spaces' in the Town Planning Review. ${ }^{65} \mathrm{He}$ had been involved in the London Society Development Plan, and had been the Chief Town Planning Inspector in the Ministry of Health since its establishment in 1919 and a member of the Unhealthy Areas Committee between 1920 and 1921. While at the 1910 Conference he was pushing forward the idea of a 'great girdle' around London in a regional plan, in the 1923 article he called for a combined approach between ring and radial park system models. Pepler stated that the function of green spaces, other than being recreational, was to form ventilating ports into town centres, for which green wedges were the best choice available. He presented a diagram featuring a park system for a town of 45,000 inhabitants with four 'park wedges' connecting the centre to the open country, four other parks and a parkway linking them together. The 'park wedges' were to be implemented by preserving open land between the developments that followed main radial roads. Pepler proposed that the built-up area would come into direct contact with the country and that the wedges of greenery would merge with it. It is important to realise that with this paper Pepler stepped away from his previous focus on the ring and the Garden City model to bring green wedges to, at least, the same level of importance as the greenbelt. (Figure 5).

Figure 5. G. L. Pepler's park system diagram, 1923.

Source: Pepler, "Open Spaces", 15.

Four years after 'Open Spaces', the Ministry of Health formed the Greater London Regional Planning Committee (GLRPC), whose task was to prepare a plan encompassing a 25 mile-radius area from Charing Cross. In January 1929, Unwin who had been the Chief Technical Officer for Building and Town Planning at the same Ministry until 1928 - was given the opportunity to carry on the work developed at the London Society when he was appointed as the Committee's technical adviser. As Miller showed, soon after his nomination Unwin announced that the Committee had studied the provision of open spaces in the form of 'a green girdle or chain of open spaces', drawing on Pepler's and Crow's ideas presented at the RIBA Town Planning Conference. ${ }^{66}$ However, in the Memorandum No.1 of the First Report of the GLRP Committee from the end of 1929, Unwin goes beyond that and, as incipiently explored in the Development Plan and confidently suggested by Pepler in his 1923 paper, presents a park system for Greater London in which both the ring and the radial models are combined. Unwin defended an inversion in the prevalent logic of planning based on designing meagre patterns of open space on a background of potential building land, in favour of considering the green background as a reserve for the creation of open spaces as required. The main features of the proposed park system were the green girdle and a series of tentative green wedges. ${ }^{67}$ The memorandum reinforced the need to find ways to reserve from building areas of land adequate to provide 'breaks and breathing spaces between the built-up zones, from which additions can be made to the parks, pleasure grounds and playing fields as required from time to time' ${ }^{68}$ It is worth highlighting that the plan was commissioned by the Ministry of Health and that the adequate provision of open spaces was one of its main directives. As Pepler showed in 'Open Spaces', and others prior to him, the green wedges had an additional beneficial factor over other kinds of green spaces, inasmuch as they supposedly funnelled fresh air into cities, which would help combat pollution and minimise the incidence of health diseases. While it is likely that Lanchester was behind the advent of green wedges in the London Society Plan, Pepler's influence in 
the 1929 GLRPC plan is undeniable. Unwin in turn opted for a closed system in which the green wedges would be contained by a 'girdle'. ${ }^{69}$ In the Second Report of the GLRPC, from 1933, Unwin reinforced the option for the expansion of large towns by developing new urban areas, as opposed to by continuous growth, a view that would be substantiated by the Barlow Report and carried out in Abercrombie's Greater London Plan. That being the case, the use of green wedges - as per the First Report - would not presuppose an indeterminate expansion, but would work alongside the girdle to create a closed park system. Although the green wedges illustrated in the 1929 report appear to have been squashed in the 1933 report as the green girdle had been pushed closer to the urbanised area, they are still evident, particularly in the south-eastern part of the plan. ${ }^{70}$ (Figure 6)

Figure 6. Illustration no 15 of the 1929 GLRPC Development plan and illustration no.12 of the 1933 GLRPC Development plan.

Source: GLRPC, First Report, face 17 and GLRPC, Second Report, between 32 and 33.

Pepler's paper would also have a significant influence on Patrick Abercrombie. In a later publication, Robert Mattocks ${ }^{71}$ showed how Abercrombie and he also used the principle of combined park system models in their 1924 plan for Sheffield. However, it was only in his 1933 book Town and Country Planning that Abercrombie was able to theorise the concept of the green wedge to some extent. As Mawson had already done in the mid-1910s, Abercrombie went on to explain the two approaches in park system planning: the concentric belts and the 'radial park wedges'. He used an embellished version of Pepler's diagram from 1923, including the same features, in which both ideas are combined. Abercrombie stressed that: 'the diagram shows a combined scheme for the town surrounded by an inviolable Green Belt of open country. (...) These major radials called by the Germans 'Ausfall Strassen' have the exhilarating effect of pointing from the centre of the largest city direct at the open country'. ${ }^{72}$

Abercrombie's book summarises how the interwar period consolidated the claim for green wedges and resolved their initial opposition to the greenbelt, since both systems tended to be combined. The direct connection to the countryside that green wedges could provide and their sanitary role were some of their most explored functions. In the post-war context, green wedges would be used as instruments of hope for a better future in both reconstruction plans and in those for new towns.

\section{Conclusions}

Despite the fact that much of the history of the development of green spaces in Britain in the first decades of the twentieth century tends to concentrate around the greenbelt and references to the Garden City, the idea of green wedges played a crucial role in the minds of planners throughout this period. Initially, there was a critical debate over whether the concentric model, with the greenbelt and ring roads at its core, or the radial model, with green wedges and radial arteries, would be the best option for the modern city. The differences and apparent opposition between these were resolved over time in favour of combined solutions, as defended by Mawson and Pepler, and as applied by Unwin and Abercrombie. In this process, the historiography tended to focus on the greenbelt and paid little attention to its radial counterpart. This paper thus puts the green wedge in a significant position in the history of park systems in the period. 
It was not until the 1910 RIBA Town Planning Conference that green wedges would emerge internationally and be propagated among the most diverse trends in urban planning. At the Conference, it was clear that the integration between radial traffic systems and park systems was one of the central topics of debate. In this context, the green wedge emerged as a fundamental typology of green space, directly connected to the need to promote radial flow, out: of transport lines to expansion areas and of people wanting to access the countryside; and in: of fresh air, sunlight and greenery. This is the moment when, incited by Eberstadt's and Lanchester's diagrams and passionate arguments, it was put to debate and reached a wider audience. The Conference Transactions were key in disseminating the idea, which could then be spread across the globe. In Britain, many planners, such as Lanchester and Mawson, became familiar with the idea and started incorporating it in their proposals. Soon after the gathering and the publication of the Transactions, Abercrombie started to defend it. Unwin did not show much enthusiasm for the application of green wedges in the British context until after Pepler's publication of 'Open Spaces', but made use of them afterwards, particularly in the GLRPC plans. Town and Country Planning, from 1933, helped popularise the idea and contained the seeds for Abercrombie's vision for London, formulated in the 1943 and 1944 plans. The use of wedges tended to focus mainly on the provision of parks, contrasting with the predominantly agricultural land that was envisaged in the post-war years for greenbelts. The green wedges did not lose esteem after World War II in the minds of planners, who would see the destruction of existing cities and the possibility of building from scratch as opportunities to implement them.

However, despite numerous attempts, green wedges - and much of what was included in the plans discussed above - did not materialise as the authors had wished. The difficulty in controlling development within urban areas and the relative ease with which land for the creation of greenbelts could be secured after the Green Belt Act of 1938 rendered the implementation of green wedges a very challenging task. Ownership patterns also had a significant impact on the comparative success of belts in relation to wedges. This would be most obvious in larger cities, such as London, where intra-urban areas necessary for the implementation of wedges would need to be of much greater size than in smaller urban areas, involving therefore many different landowners. Movements for the protection of the countryside and the consolidation of garden city ideas also contributed to the overshadowing of the wedges. The greenbelt as a leitmotif of the power of planning ideas to improve society fitted well with the predominant historiographical discourse on the prevalence of the Garden City idea in the development of British Planning, particularly with regard to the separation between town and country, the control of growth and debates over decentralisation and regional planning. ${ }^{73}$ As a concept, green wedges were not directly linked to any particular movement, country or discipline. The idea travelled across the globe, being interpreted in manifold formats since its inception. Its full story is still to be written.

\section{Note}

1. Dal Co, "From Parks to the Region", 141-293.

2. Dümpelmann, "The Park International”, 75.

3. See Munton, London's Green Belt; Sutcliffe, British Town Planning; Amati and Yokohari, "The Establishment of the London Greenbelt", 311-37; Thomas, London's Green Belt; Elson, Green Belt: Conflict Mediation; Ward, Planning the Twentieth-Century City; and Freestone, "Greenbelts in City and Regional Planning".

4. Giedion, "City Planning in the Nineteenth Century". 
5. Sutcliffe, British Town Planning; Ashworth, The Genesis of Modern British Town Planning.

6. Phillips, A Morning Walk from London to Kew, 30.

7. See The Report of the Select Committee on Public Walks, cited in Chadwick, The Park and the Town, 50-1.

8. Loudon, "Hints for Breathing Places".

9. See Schulmann, "The Hidden Roots of the Garden City Idea", 302-7 and 291-310; Panzini, Per I

Piaceri del Popolo, 166-7.

10. For a discussion about Olmsted's influence on American planning practice, see Peterson, "The Birth of Organized City Planning", 123-33; and Manieri-Elia, "Toward an 'Imperial City", 1-122.

11. Panzini, Per I Piaceri del Popolo, 287. Panzini defends that Stübben was one of the first planners to propose the notion of continuity between extra-urban routes and urban parks through linear green pathways.

12. See Hénard, Études sur les Transformations de Paris.

13. Hall, Urban and Regional Planning, 18.

14. Dümpelmann, "Creating Order with Nature", 146.

15. Whyte, "The 1910 Royal Institute of British Architects", 149-65.

16. Minutes of the RIBA Development of Towns and Suburbs Subcommittee, July 31, 1907, RIBA

Archives, v.4, 312-3. On October 18, 1907 it was reported that replies to the letters were received.

17. Lanchester, "Park Systems for Great Cities", 343.

18. H. V. Lanchester Papers Collection, RIBA Archives, LaHe/1/3. Copies of Hénard's famous "Plans Comparatifs" can be found in the collection.

19. Lanchester, "Park Systems for Great Cities", 343.

20. Ibid. Lanchester defined the parkway as "a boulevard of a less formal and more rural character".

21. Many authors have already pointed out Germany's leading role in town planning since the unification of the country in 1871. For instance, Lanchester reported to the RIBA Town Planning Committee in May 1909 that progress was being made with the translation of portions of German Town Planning Works. Minutes of the Town Planning Committee, RIBA Archives, v.5, May 18, 1909, 106-7. See also: Piccinato, La Construzione del l'Urbanística Germania 1871-1914; Luque, Constructores de la Ciudad Contemporánea; Ward, "What Did the Germans Ever Do to Us?", 117-40; Sutcliffe, Towards the Planned City.

22. See Dal Co, "From Parks to the Region", 229-30; Sutcliffe, British Town Planning; Sutcliffe, The Rise of Modern Urban Planning; Luque, Constructores de la Ciudad Contemporánea, 16; Ashworth, The Genesis of Modern British Town Planning, 193-4; and Whyte, "The 1910 Royal Institute of British Architects", 149-65.

23. Minutes of the RIBA Town Planning Sub-committee, January 7, 1910, RIBA Archives, v.5.

24. Crow, "Town Planning in Relation to Old and Congested Areas", 407-25.

25. Pepler, "Greater London", 611-20.

26. Baker, "Discussion - Cities of the Present", 242.

27. Robinson, "Cities of the Present as Representative of a Transition Period", 201-2.

28. Eberstadt, "Town Planning in Germany", 326.

29. Lanchester, "Cause and Effect in the Modern City".

30. Lanchester, "Informal Meetings: Exhibition of lantern slides", 269.

31. Hegemann, "Discussion", 240.

32. Brodie, "Discussion", 238.

33. Stasse; Bruyne, "Bruxelles Aux Champs", 648 . See also Uyttenhove, "The Garden City Education of Belgium Planners", 271-83.

34. Mawson, "Public Parks and Gardens", 435.

35. Plunkett, "Open Spaces and Running Waters", 465-75.

36. See Davidge, "The Town Planning Conference: A Review", 775-82; Journal of the Royal Institute of British Architects, "American Tribute to the Town Planning Conference", 136-7.

37. Adshead, "The Town Planning Conference", 190.

38. Town Planning Review, "The R.I.B.A Town Planning Conference Transactions", 153-4. See also

Bayard, Conférence du Town Planning.

39. Town Planning Review, "Chronicles of past events", 263.

40. Patrick Abercrombie. "Town Planning in Greater London", 264.

41. Ibid.

42. Town Planning Review, "Chronicle of past events: York Competition", 276-7.

43. Ibid.

44. Mawson, Bolton as it is and as it might be, 65-6. 
45. See particularly Hall, Cities of Tomorrow, 142-87; Ward, Planning and Urban Change; and Meller, Patrick Geddes: Social Evolutionist.

46. Hewitt, "Towards a greater urban geography", 551-68.

47. London Society, "London Society - notes of their aims", 59 - cited by Miller, "The elusive green background", 19.

48. Adams, "Town Planning in Greater London", 91- 106.

49. Miller, "The elusive green background", 18.

50. Minutes of the London Society Committee, London Society Archives, October 1, 1914.

51. Unwin, "The Berlin Exhibition of Town Planning", 17.

52. Unwin, "The City Development Plan", 250.

53. Unwin, "Some thoughts on the Development of London", 177-92.

54. Lewis, Planning of the Modern City, 146. See also Brodie. "Some notes of the Development of Wide Roads", 295-9.

55. Collins, "Urban Interchange in the Southern Cone", 208-27.

56. Von Petz, "Robert Schmidt and the public park policy", 163-82.

57. Taut, Die Städtkrone.

58. Langen, Städtebau und Wohnugsplan.

59. Agache, A Cidade do Rio de Janeiro.

60. Maia, Estudo de um Plano de Avenidas. See also Lemes de Oliveira, "Modelos Urbanísticos Modernos e Parques Urbanos".

61 . Freestone, "Exporting the garden city", 81.

62 Adams, The Building of the City, 443.

63 Johnson, Planning the Great Metropolis, 104.

64. Cherry, Cities and Plans, 80.

65. Pepler. "Open Spaces", 11-24.

66. Miller, "The elusive green background", 17; See also The Times, January 1, 1929; The Times, August 12, 1929.

67. GLRPC, First Report, 15-6.

68. Ibid.,17.

69. See Wannop and Cherry, "The Development of Regional Planning", 29-60. The appearance of green wedges in the 1929 GLRP Committee plan is acknowledged by these authors, but not explained. 70. GLRPC, Second Report, between 32 and 33.

71. Mattocks, “The Park System”, 161-83.

72. Ibid., 147-8.

73. Amati and Yokohari, "The Establishment of the London Greenbelt", 311-37.

\section{Bibliography}

Abercrombie, Patrick. "Town Planning in Greater London: the need for co-operation." Town Planning Review 2, no. 4 (1912): 261-80.

Adams, Thomas. "Town Planning in Greater London.” Town Planning Review 5, no. 2 (1914): 91-106.

Adams, Thomas, Harold Lewis, and Lawrence Orton. The Building of the City. New York: Regional Plan of New York and its Environs, 1931.

Adshead, S. D. "The Town Planning Conference of the Royal Institute of British Architects." Town Planning Review 1, no. 3 (1910): 178-90.

Agache, Alfred. A Cidade do Rio de Janeiro: Extensão, Remodelação e Embelezamento. Paris: Foyer Brésilien editor, 1930.

Amati, Marco and Makoto Yokohari. "The Establishment of the London Greenbelt: Reaching Consensis over Purchasing Land." Journal of Planning History 6, no. 4 (2007): 311-37.

Ashworth, William. The Genesis of Modern British Town Planning. London: Routledge \& Kegan Paul, 1954.

Baker, S. "Discussion - Cities of the Present." In Town Planning Conference, London, 10-15 October 1910. Transactions. [with Maps and Illustrations.], edited by the RIBA, 242. London: RIBA, 1911.

Bayard, Julien. Conférence du Town Planning: Compte Rendu a la Commission d"art et de Décoration de la Société Centrale des Architectes. Paris: Société Centrale des Architectes, 1911.

Benevolo, Leonardo. The Origins of Modern Town Planning. London: Routledge and Kegan Paul, 1967. 
Brodie, John “Discussion”, In Town Planning Conference. Transactions, 238.

Brodie, John. "Some notes of the Development of Wide Roads for Cities." Town Planning Review 5, no. 4 (1915): 295-9.

Chadwick, Georges. The Park and the Town : Public Landscape in the 19th and 20th Centuries. London: Architectural Press, 1966.

Cherry, Gordon. Cities and Plans: the Shaping of Urban Britain in the Nineteenth and Twentieth Centuries. London: Edward Arnold, 1988.

Cherry, Gordon. The Evolution of British Town Planning : A History of Town Planning in the United Kingdom During the 20th Century and of the Royal Town Planning Institute, 1914-74. Leighton Buzzard: L. Hill, 1974.

Choay, Françoise. L’urbanisme, Utopies et Réalités : une Anthologie. Paris: Seuil, 1965.

Collins, Christiane Crasemann. "Urban Interchange in the Southern Cone: Le Corbusier (1919) and Werner Hegemann (1931) in Argentina." The Journal of the Society of Architectural Historians 54, no. 2 (1995): 208-27.

Crow, Arthur. "Town Planning in Relation to Old and Congested Areas, with Special Reference to London." In Town Planning Conference. Transactions, 407-25.

Dal Co, Francesco. "From Parks to the Region", in The American City : From the Civil War to the New Deal, edited by Giorgio Ciucci, 141-293. London: Granada, 1980.

Davidge, W. R. "The Town Planning Conference: A Review." Journal of the Royal Institute of British Architects XVII, Oct 22 (1910): 775-82

Dümpelmann, Sonja. "Creating Order with Nature: Transatlantic Transfer of Ideas in Park System Planning in Twentieth century Washington D.C., Chicago, Berlin and Rome." Planning Perspectives 24, no. 2 (2009): 143-73.

Dümpelmann, Sonja. "The Park International: Park System Planning as an International Phenomenon at the Beginning of the Twentieth Century." GHI Bulletin, no. 37 (2005): 75-86.

Eberstadt, Rudolf. “Town Planning in Germany: The Greater Berlin Competition”, In Town Planning Conference. Transactions, 313-32.

Elson, Martin. Green Belt: Conflict Mediation in the Urban Fringe. London: Heinemann, 1986.

Freestone, Robert. "Exporting the garden city: Metropolitan images in Australia, 1900-1930." Planning Perspectives 1, no. 1 (1986): 61-84.

Freestone, Robert. "Greenbelts in City and Regional Planning", in From Garden City to Green City: the Legacy of Ebenezer Howard, edited by Kermit Parsons, 67-98. Baltimore: John Hopkins University Press, 2003.

Giedion, Siegfried. "City Planning in the Nineteenth Century." Chap.3 in Space, Time and Architecture. New York: Harvard University Press, 1942.

Greater London Regional Planning Committee (GLRP). First Report of the Greater London Regional Planning Committee. London: Knapp, Drewett \& Sons, 1929.

Greater London Regional Planning Committee (GLRP). Second Report of the Greater London Regional Planning Committee. London: Knapp, Drewett \& Sons, 1933.

H. V. Lanchester Papers Collection, RIBA Archives, LaHe/1/3Ibid.

Hall, Peter. Cities of Tomorrow: an Intellectual History of Urban Planning and Design in the Twentieth Century. Oxford: Blackwell, 2002.

Hall, Peter. Urban and Regional Planning. London: Allen \& Unwin, 1982.

Hegemann, Werner. "Discussion”, In Town Planning Conference. Transactions, 239.

Hénard, Eugène. Études sur les Transformations de Paris. Edited by Jean-Louis Cohen. Paris: Editions l'Equerre, 1982.

Hewitt, Lucy E. "Towards a greater urban geography: regional planning and associational networks in London during the early twentieth century." Planning Perspectives 26, no. 4 (2011): 551-68.

Johnson, D. Planning the Great Metropolis: the 1929 Regional Plan of New York and its Environs. London: Taylor and Francis, 2005.

Journal of the Royal Institute of British Architects. "American Tribute to the Town Planning Conference". Journal of the Royal Institute of British Architects XVII, December 24 (1910): 1367.

Lanchester, Henry V. "Park Systems for Great Cities", The Builder, no. 95 (1908): 343-8.

Lanchester, Henry Vaughan. "Cause and Effect in the Modern City." In Town Planning Conference. Transactions, 232-4. London: RIBA, 1911.

Lanchester, Henry Vaughan. "Informal Meetings: Exhibition of lantern slides", In Town Planning Conference. Transactions, 269. London: RIBA, 1911.

Langen, Gustav. Städtebau und Wohnugsplan. Leipzig: Verlag von S. Hirzel, 1927. 
Lemes de Oliveira, Fabiano. "Modelos Urbanísticos Modernos e Parques Urbanos: as Relações entre Urbanismo e Paisagismo em São Paulo na Primeira Metade do Século XX.” PhD diss., Polytecnic School of Catalonia, Barcelona, 2008.

Lewis, Nelson Peter. Planning of the Modern City: A Review of Principles Governing City Planning. New York: John Wiley \& Sons, 1916.

Loudon, John. "Hints for Breathing Places for the Metropolis, and for Country Towns and Villages, on Fixed Principles.” Gardener's Magazine, (1829): 686-690.

Luque, José Valdivia. Constructores de la Ciudad Contemporánea : Aproximación Disciplinar a través de los Textos. Madrid: Cie Inversiones Editoriales, 2004.

Maia, Francisco Prestes. Estudo de um Plano de Avenidas para a Cidade de São Paulo. São Paulo: PMSP, 1930.

Manieri-Elia, Mario. "Toward an 'Imperial City': Daniel H. Burnham and the City Beautiful Movement." in The American City, 1-122.

Mattocks, Robert. "The Park System.” Town Planning Review 17, no. 3 (1937): 161-83.

Mawson, Thomas. Bolton as it is and as it might be - Six lectures delivered under the auspices of the Bolton Housing and Town Planning Society. Bolton: Tillotson Press, 1915.

Mawson, Thomas. "Public Parks and Gardens: Their Design and Equipment." In Town Planning Conference. Transactions, 434-49.

Meller, Helen. Patrick Geddes: Social Evolutionist and City Planner. London: Routledge, 1990.

Miller, Mervyn. "The elusive green background: Raymond Unwin and the greater London regional plan." Planning Perspectives 4, no. 1 (2007): 17.

Minutes of the London Society Committee, London Society Archives, October 1, 1914.

Minutes of the RIBA Development of Towns and Suburbs Subcommittee, July 31, 1907, RIBA Archives, v.4, 312-3.

Minutes of the Town Planning Committee, RIBA Archives, v.5, May 18, 1909, 106-7.

Minutes of the RIBA Town Planning Sub-committee, January 7, 1910, RIBA Archives, v.5.

Munton, Richard. London's Green Belt: Containment in Practice. London: George Allen \& Unwin, 1983.

Olmsted, Frederick Law. "Public Parks and the Enlargement of Towns." American Social Science Association, 1870

Panzini, Franco. Per i Piacere del Popolo: L'Evoluzione del Giardino Publico in Europa dale Origini al XX Secolo. Bologna: Zanichelli Editore, 1993.

Pepler, George L. "Greater London.” In Town Planning Conference. Transactions, 611-20.

Pepler, George L. “Open Spaces”, Town Planning Review 10, no. 1 (1923): 11-24.

Peterson, Jon. "The Birth of Organized City Planning in the United States, 1909-1910. "Journal of the American Planning Association 75, no. 2 (2009): 123-33

Phillips, Richard. A Morning Walk from London to Kew. London: J. Adlard, 1817.

Piccinato, Giorgio. La Construzione del l'Urbanística Germania 1871-1914. Roma: Officina, 1974.

Plunkett, G. T. "Open Spaces and Running Waters." In Town Planning Conference. Transactions, 465-75.

Robinson, Charles M. "Cities of the Present as Representative of a Transition Period in Urban Development - the Evidence of Standardised Streets." In Town Planning Conference. Transactions, 201-2.

Schulmann, Ulrich. "The Hidden Roots of the Garden City Idea: From John Sinclair to John Claudius Loudon." Journal of Planning History 2, no. 4 (2003): 302-7.

Stasse, E. and H. de Bruyne. "Bruxelles Aux Champs." In Town Planning Conference. Transactions, 636-53.

Stübben, Joseph. Handbuch der Architektur. Braunschweig: Vieweg, 1890.

Sutcliffe, Anthony. British Town Planning: The Formative Years, Themes in Urban History. Leicester: Leicester University Press, 1981.

Sutcliffe, Anthony. The Rise of Modern Urban Planning 1800-1914, Planning and the Environment in the Modern World. London: Mansell, 1980.

Sutcliffe, Anthony. Towards the Planned City : Germany, Britain, the United States and France 1780 1914, Comparative Studies in Social and Economic History. Oxford: Basil Blackwell, 1981.

Taut, Bruno. Die Stadtkrone. Jena: Eugen Diederichs, 1919.

Thomas, David. London's Green Belt. London: Faber and Faber, 1970.

Town Planning Review. "Chronicle of past events: York Competition." Town Planning Review 6, no.1 (1916): 275-81.

Town Planning Review. "Chronicles of past events.” Town Planning Review 1, no. 3, (1910): 263. 
Town Planning Review. "The R.I.B.A Town Planning Conference Transactions", Town Planning Review 2, no. 1 (1911): 153-4.

Unwin, “The City Development Plan.” In Town Planning Conference. Transactions, 247-65.

Unwin, Raymond. "Some thoughts on the Development of London." In London of the Future: Essays by the London Society, edited by Aston Webb, 177-92. London: Dutton, 1921.

Unwin, Raymond. "The Berlin Exhibition of Town Planning." The Builder, July 2 (1910): 17.

Unwin, Raymond. Nothing Gained by Overcrowding!. How the Garden City type of development may benefit both owner and occupier. London: P.S. King \& Son, 1912.

Uyttenhove, Pieter. "The Garden City Education of Belgium Planners around the First World War." Planning Perspectives 5, no. 3 (1990): 271-83.

Von Petz, Ursula. "Robert Schmidt and the public park policy in the Ruhr district, 1900-1930." Planning Perspectives 14, no 2 (2010): 163-82.

Wannop, Urlan and Gordon Cherry. "The Development of Regional Planning in the United Kingdom." Planning Perspectives 9, no. 1 (1994): 29-60.

Ward, Stephen. "What Did the Germans Ever Do to Us? A Century of British Learning about and Imagining Modern Town Planning." Planning Perspectives 25, no. 2 (2010): 117-40.

Ward, Stephen. Planning and Urban Change. London: Sage, 2004.

Ward, Stephen. Planning the Twentieth-Century City: the Advanced Capitalist World. Chichester: Wiley, 2002.

Whyte, William. "The 1910 Royal Institute of British Architects" Conference: A Focus for International Town Planning?" Urban History 39, no. 1 (2012): 149-65.

\section{Acknowledgements}

The author would like to thank the editor and the reviewers for their constructive comments on an earlier version of this paper.

\section{List of Figures}

Figure 1. Lanchester's 1908 diagram and park system plan for the 'Northern Environs' of London. Figure 2. Eberstadt's opposing diagrams of concentric rings and green wedges.

Figure 3. Lanchester's diagram of a model city with green wedges.

Figure 4. London Society Development plan 1918.

Figure 5. G. L. Pepler's park system diagram, 1923.

Figure 6. Illustration no 15 of the 1929 GLRPC Development plan and illustration no.12 of the 1933 GLRPC Development plan 